\title{
Stress tests on the truck frame for the purpose of the method to determine the endurance and reliability of special vehicles
}

\author{
Pawet Gotowicki ${ }^{1}$, Przemystaw Siminski ${ }^{1, *}$ \\ ${ }^{1}$ Military Institute of Armour and Automotive Technology, Poland
}

\begin{abstract}
The frame is the most vulnerable construction component of special purpose trucks. It is vital to provide reliability of that component. The article describes the stress and torsion angle tests, caused by load for the purpose of the method to determine the endurance and reliability.
\end{abstract}

\section{Introduction}

The process to implement new military vehicle is quite tedious and time consuming. One of the reasons is the long operation period, approx. 20 to 30 years. One of the basic test types that need to be performed during the initial phase, the prototype phase [1], are the endurance and reliability tests. Such tests include the determination of relevant indicators based on many test track cycles performed. [2] The assumption is to perform certain conduct for different surface types. High variability of conditions and surface profiles results in selective conditions for vehicle assemblies, where weak links are relatively easy to find and thus reducing the vehicle endurance and reliability.

The profile and the conditions of military vehicle operation impose the necessity to seek methods increasing the test performance, especially in terms of their duration. One of the approaches assumes the use of the hypothesis of defect accumulation in material to compare the load interference, described using static characteristics. It allows to compare the fatigue strength under different operating conditions and consider the rate of defect accumulation increase depending on the number of units/cycles. The obtained rates of fatigue strength increase depend on the road profile, which unfortunately rarely remains stable for unsurfaced roads. The main problem is to develop load spectrum for vehicle frame using cycle method. [3]

On the other hand, the vehicle should ensure movement smoothness. [4, 5] The frame, tires and suspension system should limit the interference: surface roughness, movement resistance since they influence the driver psycho-physical state. [6]

The tests for the needs of military vehicles on the influence of dynamic loads on movement smoothness as well as endurance and reliability do not provide strictly precise answer.

* Correspondence address: przemyslaw.siminski@witpis.eu 
Therefore, there is the need to frequently monitor the test roads profiles $[7,8]$ and to determine the influence of fatigue cycles on stresses in selected key construction nodes.

Therefore, during the first stage of works to develop global method, the specialized measurement equipment was acquired and the tests of military vehicle load impact on the stresses in vehicle frame as well as torsion angle under static conditions were performed.

\section{Measurement system}

The measurement setup for strain monitoring consists of red-out systems (fiber optic interrogator by Deminsys with specification and two fiber Bragg gratings that act as strain sensors. Measured data are transferred to PC via 100Mbps LAN. Due to the similar Bragg wavelength of both FBGs, they were connected separately to two channels of the interrogator.

When the force is applied to the FBG, its Bragg wavelength shift in the reflected/transmitted spectrum is observed due to the grating length (and thus grating period) and refractive index changes.

$$
\frac{\Delta \lambda}{\lambda_{0}}=k * \varepsilon * \alpha_{s} * \Delta T
$$

Strain values were measured and recorded using digital-storage-oscilloscope Hioki 8847 with Hioki 8969 Strain Unit and a Kyowa DB-120A Bridge Box for Dynamic Strain Measuring Instruments. Self-temperature-compensated (composite and steel) gages Vishay CEA-06-250UN-120 in the three-wire quarter-bridge circuit arrangement were used. The stresses were determined by the strain gages set on the axial center of side members of chassis. The gage length is $6,35 \mathrm{~mm}$ and nominal grid resistance $120 \Omega$. The dynamic response of this strain measuring system is $20 \mathrm{kHz}$. The $\sigma$ and $\tau$ stress values were calculated from the measured strain $\varepsilon$, according to Hooke's Law for the uniaxial stress state. Hioki 8847 Memory HiCorders are high-speed waveform monitoring and recording devices that can simultaneously measure multiple physical phenomena such as voltage, current, temperature, vibration, acceleration and rotation due to complete isolation between channels and from each channel to the ground. VISHAY CEA-06-250UN-120 universal general-purpose strain gages: Strain range $\pm 5 \%$, Temperature range $-75^{\circ}$ to $+175^{\circ} \mathrm{C}$, Grid resistance $120 \Omega \pm 0.3 \%$, Gage length 6.35, Overall length 10.54, Grid width 3.05, Overall width 3.05, Matrix length 13.2, Matrix width 5.6; Gage factor $2,14 \pm 0.5 \%$, Transverse sensitivity $+0,6 \pm 0.2 \%$, Temperature coefficient of gage factor $+1,2 \pm 0.2 \% / 100^{\circ} \mathrm{C}$. KYOWA DB-120A Bridge Box for Dynamic Strain Measuring Instruments: Number of Input Channels 1; Connecting target Strain gage; Strain Method: Quarter bridge 2-wire system, Quarter bridge 3-wire system, Half bridge system, Opposite side 2-active-gage system and Full bridge system; Applicable Strain Gage Resistance $120 \Omega$.

\section{Tests}


The test object was a truck, STAR 1466 used in the military. Its load capacity is 6 tones and the power transmission system configuration is $6 \times 6$. The tests were initiated with the measurement of STAR 1466 curb weight using three different load variants:

- With real curb weight (without driver),

- With additional substitution weight of 5,902 kg, 3,147 kg placed on vehicle open load-carrying body and without load.

The vehicle was fully equipped with full fuel and fluid tanks.

Next, using laser measuring instrument, the axle articulation was measured for different location of height hoist under the wheels of each axis, using three load variants described above. At the same time the vehicle height from surface and bumper height were measured in order to determine the torsion angle in the transverse plane.

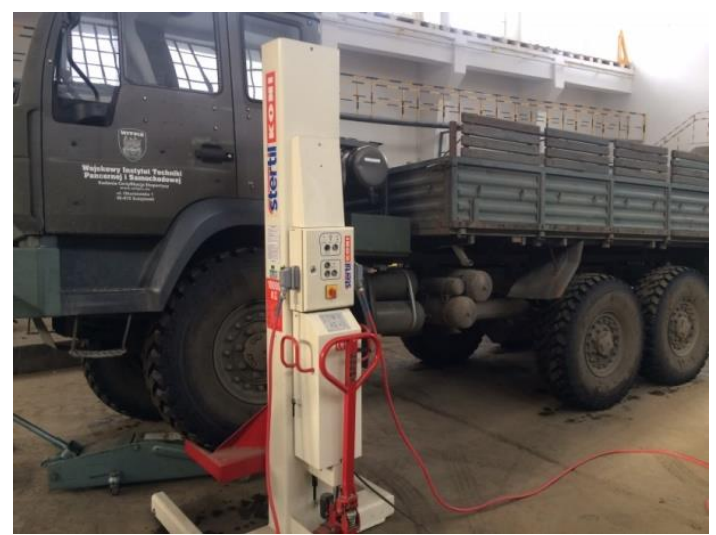

Fig. 1. Forcing of frame deformation.

The example measurement results of STAR 1466 axle articulation is presented in Table 1.

Table 1. Results of frame articulation for example load variants.

\begin{tabular}{|c|c|c|c|c|}
\hline \multicolumn{5}{|c|}{ STAR 1466 axle articulation - measured values } \\
\hline $\begin{array}{c}\text { Ite } \\
\mathrm{m}\end{array}$ & Measured parameter & $\begin{array}{c}\text { Measuremen } \\
\text { tresult }\end{array}$ & Measured parameter & $\begin{array}{c}\text { Measuremen } \\
\text { t result }\end{array}$ \\
\hline 1 & 2 & 3 & 4 & 5 \\
\hline \multicolumn{5}{|c|}{ Vehicle in the basic location - variant 0 } \\
\hline 1. & $\begin{array}{c}\text { The hydraulic hoist height - } \\
\text { left wheel of 1st axis }\end{array}$ & $0 \mathrm{~m}$ & $\begin{array}{c}\text { The hydraulic hoist height - } \\
\text { right wheel of 3rd axis }\end{array}$ \\
\hline
\end{tabular}




\begin{tabular}{|c|c|c|c|c|}
\hline \multicolumn{5}{|c|}{ STAR 1466 axle articulation - measured values } \\
\hline $\begin{array}{l}\text { Ite } \\
\text { m }\end{array}$ & Measured parameter & $\begin{array}{l}\text { Measuremen } \\
\text { t result }\end{array}$ & Measured parameter & $\begin{array}{l}\text { Measuremen } \\
\text { t result }\end{array}$ \\
\hline 2. & $\begin{array}{c}\text { The 1st axis wheel height - } \\
\text { left side }\end{array}$ & $0.590 \mathrm{~m}$ & $\begin{array}{c}\text { The 1st axis wheel height - } \\
\text { right side }\end{array}$ & $0.576 \mathrm{~m}$ \\
\hline 3. & $\begin{array}{c}\text { The front bumper height - } \\
\text { left side }\end{array}$ & $0.926 \mathrm{~m}$ & $\begin{array}{c}\text { The front bumper height - } \\
\text { right side }\end{array}$ & $0.903 \mathrm{~m}$ \\
\hline 4. & $\begin{array}{l}\text { The frame height in the } \\
\text { vicinity of 1st axis - left }\end{array}$ & $0.943 \mathrm{~m}$ & $\begin{array}{l}\text { The frame height in the } \\
\text { vicinity of } 1 \text { st axis - right side }\end{array}$ & $0.926 \mathrm{~m}$ \\
\hline 5. & $\begin{array}{l}\text { The frame height between } \\
\text { the 2nd and 3rd axis - left }\end{array}$ & $0.932 \mathrm{~m}$ & $\begin{array}{l}\text { The frame height between the } \\
\text { 2nd and 3rd axis - right side }\end{array}$ & $0.922 \mathrm{~m}$ \\
\hline 6. & $\begin{array}{c}\text { The rear bumper height - } \\
\text { left side }\end{array}$ & $0.442 \mathrm{~m}$ & $\begin{array}{l}\text { The rear bumper height }- \text { left } \\
\text { side }\end{array}$ & $0.391 \mathrm{~m}$ \\
\hline \multicolumn{5}{|c|}{ Vehicle in location - variant 1} \\
\hline 7. & $\begin{array}{c}\text { The hydraulic hoist height - } \\
\text { left wheel of 1st axis }\end{array}$ & $0.213 \mathrm{~m}$ & $\begin{array}{l}\text { The hydraulic hoist height - } \\
\text { right wheel of 3rd axis }\end{array}$ & \\
\hline 8. & $\begin{array}{c}\text { The 1st axis wheel height - } \\
\text { left side }\end{array}$ & & $\begin{array}{c}\text { The 1st axis wheel height - } \\
\text { right side }\end{array}$ & $0.567 \mathrm{~m}$ \\
\hline 9. & $\begin{array}{c}\text { The front bumper height - } \\
\text { left side }\end{array}$ & $1.111 \mathrm{~m}$ & $\begin{array}{c}\text { The front bumper height - } \\
\text { right side }\end{array}$ & $0.960 \mathrm{~m}$ \\
\hline 10. & $\begin{array}{l}\text { The frame height in the } \\
\text { vicinity of 1st axis - left }\end{array}$ & $1.032 \mathrm{~m}$ & $\begin{array}{l}\text { The frame height in the } \\
\text { vicinity of } 1 \text { st axis - right side }\end{array}$ & $0.978 \mathrm{~m}$ \\
\hline 11. & $\begin{array}{l}\text { The frame height between } \\
\text { the } 2 \text { nd and 3rd axis - left }\end{array}$ & $0.952 \mathrm{~m}$ & $\begin{array}{l}\text { The frame height between the } \\
\text { 2nd and 3rd axis - right side }\end{array}$ & $0.925 \mathrm{~m}$ \\
\hline 12. & $\begin{array}{c}\text { The rear bumper height - } \\
\text { left side }\end{array}$ & $0.426 \mathrm{~m}$ & $\begin{array}{l}\text { The rear bumper height - left } \\
\text { side }\end{array}$ & $0.352 \mathrm{~m}$ \\
\hline
\end{tabular}

The object was prepared for stress measurements by taping extensometers to 3 selected points on the vehicle frame (Fig. 4). These points were selected based on the operation experience as potentially exposed to substantial stresses. 


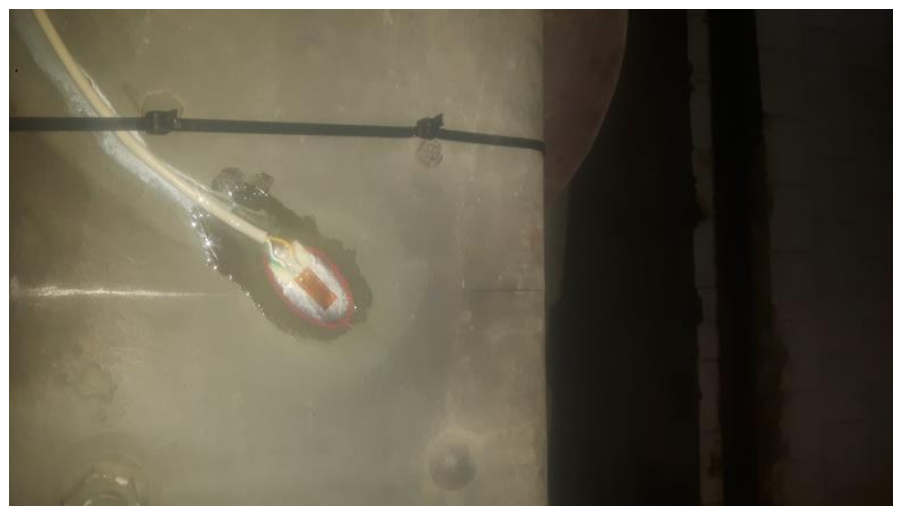

Fig. 4. The example of taped extensometers to selected points on the vehicle.

The stress result measured in the selected frame points for different vehicle loads is presented in Fig. 5. The wheel was lifted with the stroke of every $10 \mathrm{~mm}$ within the range of $0 \mathrm{~mm}$ to $50 \mathrm{~mm}$ and $50 \mathrm{~mm}$ to $0 \mathrm{~mm}$.

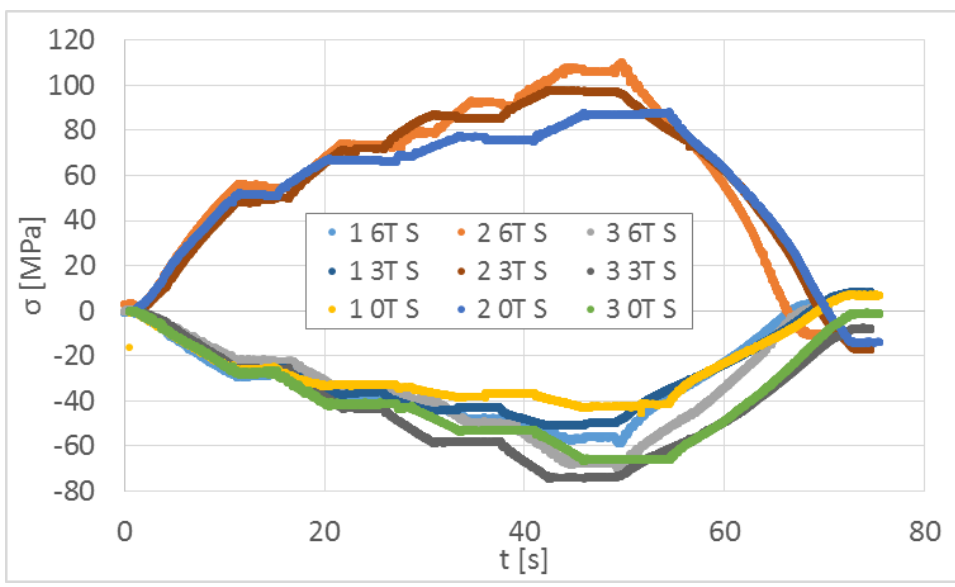

Fig. 5. The stress characteristics (normal stress and shearing stress of beam profile) caused by frame torsion for different vehicle loads: 1 - shearing stress $\tau$ in the middle of beam web profile; 2 - normal stress $\sigma$ on the upper part of beam profile; 3 - normal stress $\sigma$ on the lower part of beam profile.

As per the expectations, the highest stress values with the value of $110 \mathrm{MPa}$ were obtained for the vehicle load of 6 tones. The highest stress values are present in the normal direction on the upper part of the beam profile. In the tested STAR 1466 model this part is especially prone to damage. The operation practice showed that in points 2 and 3 there are cracks during the off-road drive with maximum load. The tests [9] proved that the stress in the truck 
standard frame, moving with low speed of $40 \mathrm{~km} / \mathrm{h}$ on relatively even surface are at the level of $80 \mathrm{MPa}$. The measured value of $110 \mathrm{MPa}$ for $18 \mathrm{G} 2 \mathrm{~A}$ unalloyed steel is already a critical value in the static state.

The frame torsion angle was measured to thoroughly observe the impact of open loadcarrying body load. These test results are presented in Fig. from 6 through 8 .

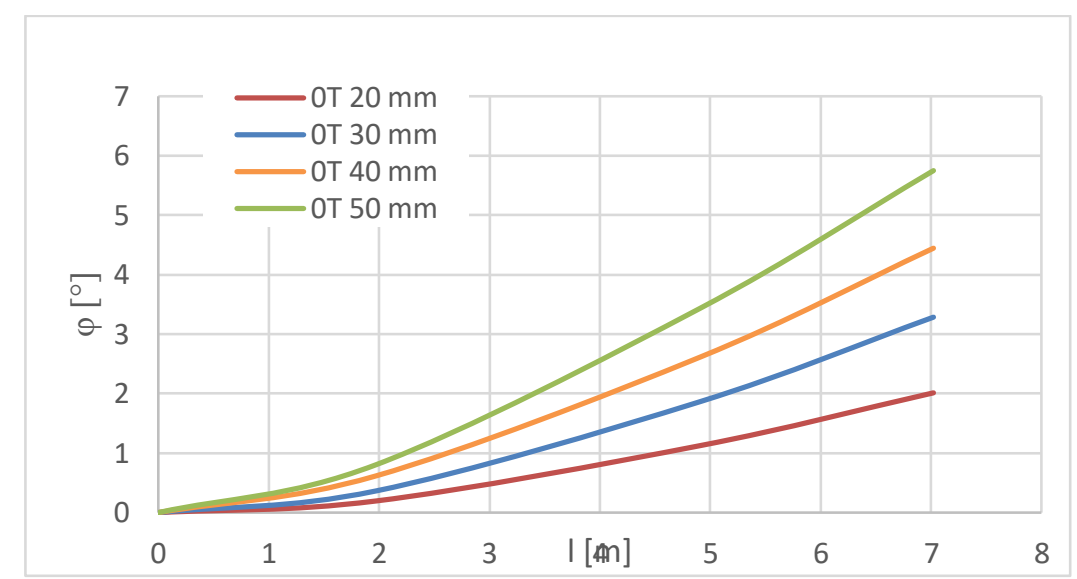

Fig. 6. The characteristics of vehicle frame torsion angle for different forcing without load in open load-carrying body

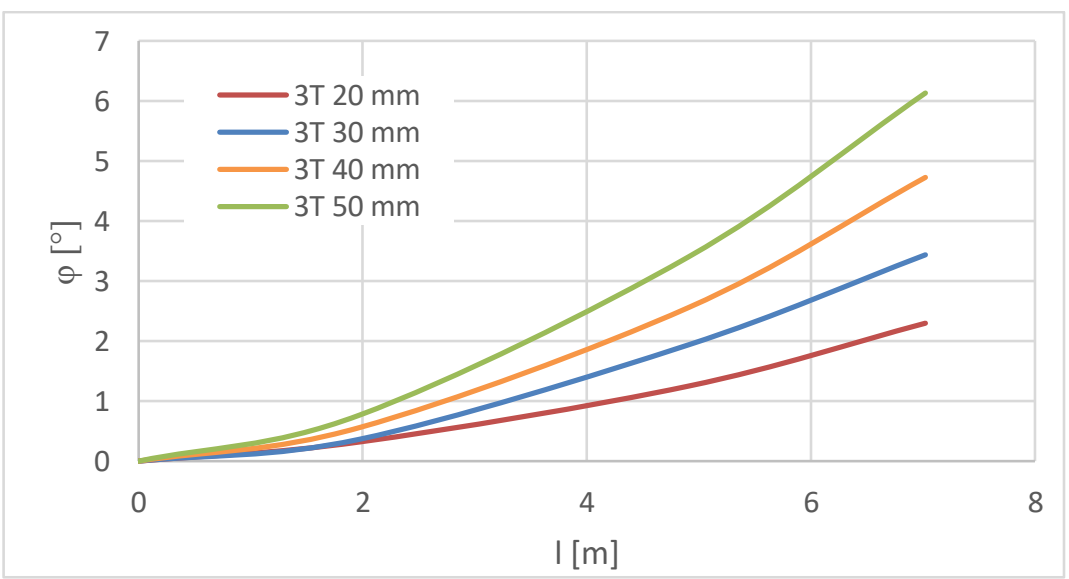

Fig. 7. The characteristics of vehicle frame torsion angle for different forcing with load o 3 tonnes in open load-carrying body 


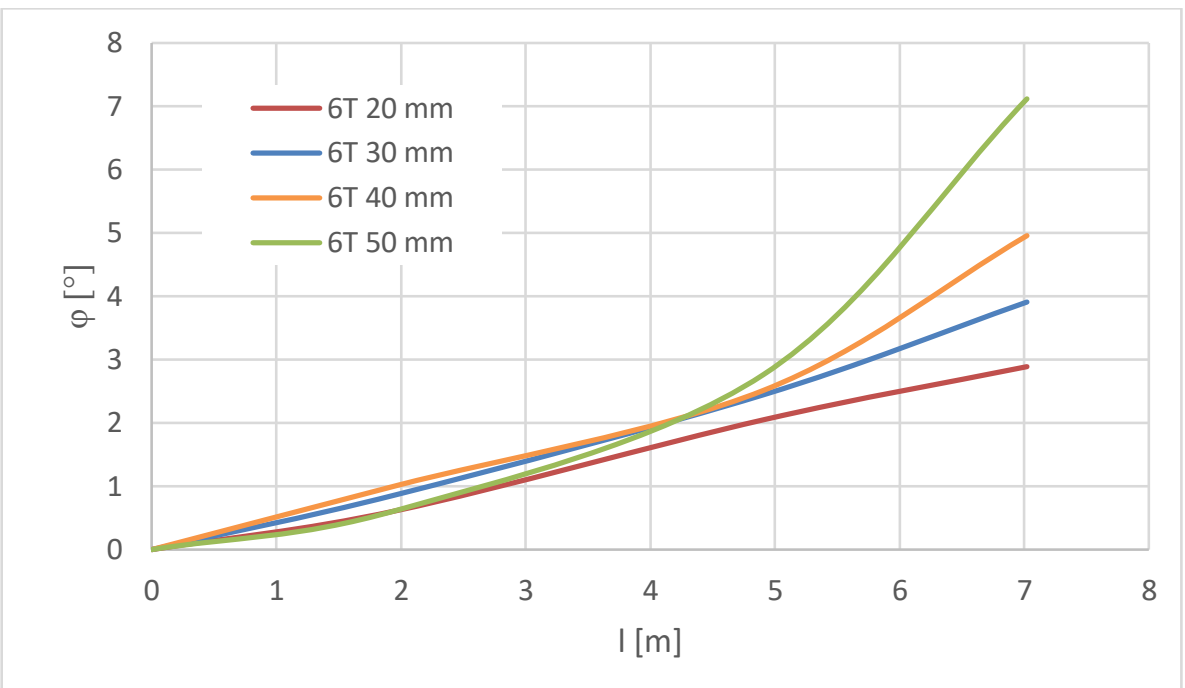

Fig. 8. The characteristics of vehicle frame torsion angle for different forcing with load of 6 tons in open load-carrying body

The frame torsion angle changes in a non-linear manner and the higher dynamics of angle change takes place for the load of 6 tons and $50 \mathrm{~mm}$ forcing under the wheel. This is the information that the frame operation on torsion during off-road drive should be analyzed during each new development or fame design.

The presented test results can be used to verify the numeric model of vehicle frame. The designed measurement system can be used to dynamic tests on unsurfaced roads.

The deformation measurement method using type FBG optical sensors indicates features and parameters that allow the performance of tests of composite and metal construction elements and vehicles with static, percussive and operational loads.

The presented methods of experimental analysis of deformations and stresses are used to:

- Determine the characteristics of construction material mechanical properties

- Test the distribution as well as deformation and stress values in the construction elements or in their models, especially when determining the stress concentration.

- Determine the internal forces in construction elements subject to operational load.

- Determine own stresses, e.g. assembly, casting, welding stresses and stresses from heat loads etc.

- Determine the characteristic values for deformation and construction movement state (displacement, speed, acceleration).

\section{References}


1. S. Niziński, Eksploatacja obiektów technicznych (Instytut Technologii Eksploatacji, 2002)

2. P. Simiński, Wojskowe Pojazdy Kołowe, (2015)

3. TOP 01-1-010A Vehicle Test Course Severity (Surface Roughness)

4. https://www.matecconferences.org/articles/matecconf/pdf/2015/12/matecconf_icmee20 15_02002.pdf

5. https://www.sciencedirect.com/science/article/pii/S002248980600005X

6. W. Luty, W. Kupicz, M. Zwierzyński, Examination and assessment of special purpose vehicle crews' comfort while operating in off-road conditions 49 ( Zeszyty Naukowe Wyższa Szkoła Oficerska Wojsk, 2017)

7. TOP 02-2 TOP 01-1-010A -506A Wheeled and Tracked Vehicle Endurance Testing

8. TOP 1-1-030 RAM-D and ILS Analysis

9. M. Miros, Wpływ napraw spawalniczych na właściwości eksploatacyjne elementów nośnych pojazdów ciężarowych, $\mathrm{PhD}$ thesis, (Politechnika Ślaska 2010) 